\title{
A Special Message to Students and Graduates About Publishing in a Journal
}

\author{
George A. Zangaro, $\mathrm{PhD}, \mathrm{RN}, \mathrm{FAAN}$ \\ Walden University, Minnesota, United States \\ (iD) https://orcid.org/0000-0002-9739-0089
}

Diane Whitehead, EdD, DNP, RN, ANEF

Walden University, Minnesota, United States

Contact: George.Zangaro@mail.waldenu.edu

\section{Recommended Citation}

Zangaro, G. A., \& Whitehead, D. (2019). A special message to students and graduates about publishing in a journal. Journal of Excellence in Nursing and Healthcare Practice, 1, 1-3. https://doi.org/10.5590/JENHP.2019.1.1.01

The Journal of Excellence in Nursing and Healthcare Practice (JENHP) was created to promote innovations, translation, and dissemination of evidence supporting improved outcomes in the nursing practice environment. The journal welcomes manuscripts focusing on topics such as national and international workforce issues, quality improvement projects, evidenced-based practice initiatives, nursing research studies, interprofessional practice, educational issues, improvements in technology, innovative practice problem solutions, and the impact of social change in society. Although we accept submissions from all types of researchers, both new and experienced, one central purpose of this journal is to provide an outlet for research conducted by students. Hence, individuals from doctoral, master's, and baccalaureate programs are especially welcomed to submit manuscripts based on scholarly projects or papers completed while in or after graduating from an accredited program.

For doctoral students in particular, defending a dissertation or capstone project is the final milestone in your educational experience. Because research is not complete until the findings of a study are presented and/or published, the next step in your professional journey should involve sharing all that hard work with others. Dissemination of your conclusions may be through an oral or poster presentation at a conference or publishing the findings in a peer-reviewed journal, such as JENHP.

Table 1 provides several reasons why dissertation and capstone project findings should be disseminated. All of these reasons are important, but informing the scientific community, advancing nursing knowledge, and translating knowledge are three of the most critical aspects because decreasing the research-practice gap through the dissemination and translation of knowledge is essential to providing safe, efficient healthcare that will satisfy all of the consumers.

Upon completion of your doctoral program, you may find a void in your day that you need to fill, so give yourself some dedicated time to write a manuscript to disseminate your findings. A first step may be to consult your supervisory committee for guidance on where to publish and some helpful hints for success. This committee of scientists has spent many hours reviewing and editing your work, and as a result, you should feel confident that the science is sound and worthy of publication. 
Transforming the dissertation or capstone into a publication will require some work, as a journal article is typically much shorter and more concise than the original document, but it is critical that you meet the mission, aims, and guidelines of the journal in which you decide to submit it for publication. There are several peer-reviewed articles that discuss how to transition a dissertation or capstone into a published article (Carter-Templeton, 2015; Resnick, 2013, 2015, 2017; Steefel \& Saver, 2013).

Table 1: Dissemination of Findings

\begin{tabular}{lc}
\hline Reason & Details \\
\hline 1. Inform scientific community & $\begin{array}{c}\text { Publishing makes your work available to other scientists who may use your } \\
\text { research to support a similar finding or conclusion in their own work. }\end{array}$ \\
$\begin{array}{l}\text { 2. Advance nursing and } \\
\text { healthcare knowledge }\end{array}$ & $\begin{array}{c}\text { Nurse-led research improves patient outcomes, reduces costs, and } \\
\text { increases patient satisfaction through the presentation of new clinical } \\
\text { findings and validation of best practices to advance nursing science. }\end{array}$ \\
$\begin{array}{l}\text { 3. Translate knowledge } \\
\text { Translating knowledge into clinical practice is a critical step in reducing } \\
\text { the research-practice gap in nursing. } \\
\text { satisfaction }\end{array}$ & $\begin{array}{c}\text { A doctorate requires a lot of time, money, and energy; you deserve to be } \\
\text { recognized in the literature for all of the effort on your dissertation or } \\
\text { capstone project. }\end{array}$ \\
$\begin{array}{l}\text { 5. Enhance professional career } \\
\text { A publication or presentation will enhance an academic or clinical career } \\
\text { and assist you in establishing credibility in the field. }\end{array}$ \\
$\begin{array}{c}\text { Through dissemination of your work, you allow others in your area of } \\
\text { interest to read your work and increase collaboration with other } \\
\text { scientists; leaders in the field may invite you to collaborate on a project. }\end{array}$ \\
\hline
\end{tabular}

Most importantly, writing a manuscript to inform the public about the findings so that they can be translated into practice is everyone's professional obligation. Therefore, as the editors of JENHP and scholars ourselves, we strongly encourage students to submit a manuscript based on their dissertation or capstone project to be considered for publication, whether in JENHP or another source.

We are excited to serve as the editors of this exciting new journal. If you choose JENHP, we look forward to sharing your submissions with our review board, providing you feedback on your work, and possibly sharing your contributions to nursing and healthcare science with colleagues across the globe.

\section{References}

Carter-Templeton, H. (2015). Converting a DNP scholarly project into a manuscript. Nurse Author \& Editor, 25, 2. Retrieved from http://naepub.com/student-authorship/2015-25-1-2/

Resnick, B. (2013). Publishing a DNP capstone: The where, what and how. Geriatric Nursing, 34, 95-97. https://doi.org/10.1016/j.gerinurse.2013.02.003

Resnick, B. (2015). Academic authorship guidelines for capstone and dissertation work. Geriatric Nursing, 36, 421-422. https://doi.org/10.1016/j.gerinurse.2015.10.001

Resnick, B. (2017). From capstone/dissertation to publication: Let's try this again! Geriatric Nursing, 38 , 95-96. https://doi.org/10.1016/j.gerinurse.2017.03.002 
Steefel, L., \& Saver, C. (2013). From capstone project to published article. American Nurse Today, 8, 1-3. Retrieved from http://www.doctorsofnursingpractice.org/wpcontent/uploads/2014/01/SaverHandoutPDF2013Workshop.pdf telehealth, improvements in technology, and the impact of social change in society. 